\title{
Mental health assistance in Primary Care: the perspective of professionals from the Family Health Strategy
}

\author{
Assistência em saúde mental na Atenção Primária: perspectiva dos profissionais da Estratégia Saúde da Família
}

Asistencia en salud mental en la Atención Primaria: perspectiva de los profesionales de la Estrategia de Salud Familiar

Luana Cristina Bellini Cardoso' ORCID: 0000-0001-8460-1177

Sonia Silva Marcon' ORCID: 0000-0002-6607-362X

Thamires Fernandes Cardoso da Silva Rodrigues' ORCID: 0000-0001-7942-4989

Marcelle Paiano' ORCID: 0000-0002-7597-784X

Hellen Emília Peruzzo" ORCID: 0000-0002-0786-0447

Bianca Cristina Ciccone Giacon-Arruda"I ORCID: 0000-0002-8433-6008

Leandro Barbosa de Pinho'v ORCID: 0000-0003-1434-3058

'Universidade Estadual de Maringá. Maringá, Paraná, Brazil. "Universidade Estadual do Paraná. Paranavaí, Paraná, Brazil. I'Universidade Federal de Mato Grosso do Sul. Campo Grande, Mato Grosso do Sul, Brazil. "Universidade Federal do Rio Grande do Sul. Porto Alegre, Rio Grande do Sul, Brazil.

How to cite this article: Cardoso LCB, Marcon SS, Rodrigues TFCS, Paiano M, Peruzzo HE, Giacon-Arruda BCC, et al. Mental health assistance in Primary Care: perspective of professionals from the Family Health Strategy. Rev Bras Enferm. 2022;75(Suppl 3):e20190326 https://doi.org/10.1590/0034-7167-2019-0326

Corresponding author: Luana Cristina Bellini Cardoso E-mail: luana.bellini@hotmail.com

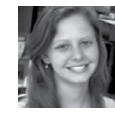

EDITOR IN CHIEF: Antonio José de Almeida Filho ASSOCIATE EDITOR: Italo Rodolfo Silva

\section{ABSTRACT}

Objective: To learn about the perceptions of the professionals who work in Primary Health Care about mental health care. Methods: Descriptive and qualitative study, carried out with 29 health workers through open and individual interviews. The IRaMuTeQ ${ }^{\circ}$ software was used to organize the data which, then, was submitted to a content analysis process in the thematic modality. Results: Three classes emerged from the content analysis: "Perceptions about the mental health care provided in the city", "The biomedical paradigm in mental healthcare", and "Elements for the construction of a new way for professionals to act in mental health". Final considerations: It was found that, despite the good infrastructure of the services and the elements pointed at by the professionals to create a new way to act, they do not do so, and the responsibility falls, mostly, on the psychologist to carry out these activities. Descriptors: Nursing; Mental Health Assistence; Primary Health Care; Family Health Strategy; Health Policy.

\section{RESUMO}

Objetivo: Apreender as percepções dos profissionais que atuam na Atenção Primária à Saúde sobre a assistência em saúde mental. Métodos: Estudo descritivo, qualitativo, realizado com 29 profissionais de saúde, mediante entrevistas abertas e individuais. Adotou-se o software IRaMuTeQ para organização dos dados, após a qual foram submetidos ao processo de análise de conteúdo de modalidade temática. Resultados: Da análise de conteúdo, emergiramse três classes: "Percepções sobre o atendimento de saúde realizado no município", "O paradigma biomédico na assistência de saúde mental", "Elementos para a construção de um novo fazer profissional em saúde mental". Considerações finais: Notou-se que, apesar da boa infraestrutura dos serviços e de os profissionais apontarem alguns elementos para a construção de um novo fazer profissional, eles não o realizam, recaindo, maiormente, sobre o psicólogo a responsabilidade de conduzir tais atividades.

Descritores: Enfermagem; Assistência à Saúde Mental; Atenção Primaria à Saúde; Estratégia Saúde da Família; Política de Saúde.

\section{RESUMEN}

Objetivo: Aprehender las percepciones de los profesionales que actúan en la Atención Primaria de Salud sobre la asistencia en salud mental. Métodos: Estudio descriptivo, cualitativo, realizado con 29 profesionales de salud, mediante entrevistas abiertas e individuales. Se adoptó el software IRaMuTeQ para organización de los datos, tras la cual fueron sometidos al proceso de análisis de contenido de modalidad temática. Resultados: Para el análisis de contenido, emergieron tres clases: "Percepciones sobre la atención de salud realizado en el municipio", "El paradigma biomédico en la asistencia de salud mental", "Elementos para la construcción de un nuevo hacer profesional en salud mental". Consideraciones finales: Se notó que, aunque la buena infraestructura de los servicios y de los profesionales apuntaren algunos elementos para la construcción de un nuevo hacer profesional, ellos no lo realizan, recayendo, mayormente, sobre el psicólogo la responsabilidad de conducir tales actividades. Descriptores: Enfermería; Atención a la Salud Mental; Atención Primaria de Salud; Estrategia de Salud Familiar; Política de Salud. 


\section{INTRODUCTION}

The integration of mental health into the Primary Health Care (PHC) is a part of the daily lives of the teams in this level of care. Its benefits are the easier access to assistance and the greater likelihood of positive results, due to the fact that the services are close to the community. It also makes it possible to manage and monitor cases in the long term, preventing against acute events, promoting respect to human rights, and minimizing the stigma and discrimination ${ }^{(1)}$.

However, despite these benefits, PHC workers do not feel prepared to address mental health demands ${ }^{(2)}$, and the practices of mental health care developed in this field are often not seen as what they are, and become unviable ${ }^{(3)}$. This lack of preparation may be associated to the lack of human resources and to the difficulty of understanding the social determinants of the area they are in, which lead to the psychic suffering of the population. This, therefore, leads to therapies that are not resolutive, perpetuating an inadequate use of services and unnecessary referrals ${ }^{(3-4)}$.

Literature shows that $\mathrm{PHC}$ professionals, especially physicians and nurses, feel overloaded, believing that mental health practices are restricted to a group of experts in the subject and showing a fragmented knowledge about the role of these practices in the $\mathrm{PHC}$, which is focused on curative individual action ${ }^{(2,5)}$. According to the professionals, the biomedical model is still strongly associated with the mental health actions in primary care, being characterized mostly by indiscriminate prescriptions of psychotropic drugs and the renovation of prescriptions ${ }^{(6-8)}$.

The PHC teams must be prepared for timely evaluations and interventions, based on technical and scientific knowledge and on abilities to provide both individual and collective care. Furthermore, it is also necessary to get patient relatives involved in the therapeutic plans, to reorganize mental health care, and recognize the potential of the Health Care Network ${ }^{(9-10)}$.

However, it must be highlighted that care provided to people who are under mental distress or have mental disorders, according to the Family Health Strategy (ESF), is still a seldom explored topic. Studies in the field address the perceptions of the professionals, but not those related to the work process, to the management of people, and to the way in which mental health assistance takes place in the PHC. Considering the above, and the fact that these workers go through this experience in their daily work providing assistance, this study believes that their perspectives can subsidize tools to improve the work process and address the needs of the population.

\section{OBJECTIVE}

To learn the perceptions of professionals who work in Primary Care about mental health care to people under psychic distress.

\section{METHODS}

\section{Ethical aspects}

This study was developed based on Resolutions No. 446/12 and $510 / 2016$, from the National Council of Health. It was approved by the Permanent Ethics Committee for Researches with Human
Beings. To preserve the anonymity of the participants, they were identified using the Portuguese abbreviation of their profession (Enf - Nurse; Psic: Psychologist; Med - Physician), followed by a number that indicated the order in which they became a part of the study (e.g. Psic-01). All of them signed the Free and Informed Consent Form.

\section{Theoretical-methodological framework}

The conceptual bases of this study can be found in Law No. 10.216 , from April 06, 2001 ${ }^{(11)}$ and on the Mental Health Guidelines of Paraná ${ }^{(12)}$.

The first, so-called "Law of Psychiatric Reform", presents a proposal to for the protection of the person under psychic suffering, establishing their rights and proposing a redirection of the model of mental health care ${ }^{(11)}$.

The Mental Health Guidelines, on the other hand, presents the Psychosocial Attention Care Network (RAPS), where those under psychic suffering receive care from several professionals who treat them considering the logic of shared responsibilities. It also included the Clinical Protocol and the Therapeutic Directives, which suggest changes in the work process.

It is based on the methodological references of content analysis, thematic modality. The content analysis is subjective concerning the "signified", although it can also be an analysis of "significants". As a result, the descriptive treatment of data is the first step of the process but is not exclusive to content analysis ${ }^{(13)}$.

\section{Type of study}

Descriptive, qualitative study. Therefore, the Consolidated criteria for reporting qualitative research (COREQ) was used to guide its methodology. This type of study allows for the understanding of the internal logic of groups and institutions, from the many perspectives that affect social processes such as culture, relations between individuals, social movements, and the implantation of public policies. Therefore, meaning and intentionality, which are necessary to clarify human meaning, are attributed to these connections $^{(14)}$.

\section{Methodological procedures}

The methodological procedure took place as follows. At first, the coordination from the Council for the Permanent Formation and Qualification of Health Workers in the city sent an email, letting the units know about the research. Then, the researchers scheduled visits to the health services, in order to present the study, its objectives, and check whether the professionals were available and interested in participating. Later, the researchers went back to the unit to schedule and do the interviews.

\section{Study setting}

The study was carried out with professionals from 19 ESF teams inserted in 6 from 34 Primary Health Care Units (UBS) from a city in the state of Paraná. The UBSs chosen were those with the highest demand for attention in the mental health field. 


\section{Source data}

The nurses and physicians from the ESF and the psychologists who worked in the UBSs were invited in person. The criteria of inclusion were: being a higher education professional who attends people in psychic suffering and being working in this position for at least six months. Were excluded community health agents $(\mathrm{CHA})$ and professionals on leave for any reason during data collection. There were 35 workers in the units who attended these criteria. Three were on leave and three refused participation due to high work demands.

The study also included three psychologists from the team of the Center for the Support to Family Health (NASF) who were in accordance with the inclusion criteria. As a result, the participants were 29 professionals, 24 nurses, 7 physicians, and 8 psychologists.

\section{Data collection and organization}

Data collection took place from February to June 2018 through semi-open interviews, conducted based on two triggering questions: "Comment about the mental health care in the city" and "Tell me how you think the assistance to people in psychic suffering should be in the Primary Health Care." Other questions were incorporated into the script when it was clear that the data was too superficial or clarifications were necessary. Sociodemographic and professional information were also collected to characterize the participants.

The interviews were carried out by a single researcher, a nurse with experience in qualitative researches, who did not have any previous contact with the participants of the study. The interviews were scheduled in advanced and lasted for a mean of 40 minutes. Each participant was interviewed once in a private room in the unit they worked, to interfere as little as possible in their duties and activities. The interviews were recorded in audio and transcribed in full, to preserve the content of the statements. Data was organized using the IRaMuTeQ 0.7 (Interface de R pour les Analyses Multidimensionnelles de Textes et de Questionnaires).

\section{Data analysis}

The statements were transcribed in full after the collection was finished. The data was analyzed according to the thematic analysis process ${ }^{(13)}$. In the pre-analysis stage, texts were skimmed twice, to choose reports, form hypotheses, choose analysis indexes and elaborate categoric indicators on which to base data interpretation. The stage of material exploration included four systematized readings aimed at forming groups and associations that responded to the objectives of the study and, thus, to build analytical categories. These groupings and associations were selected from the original material and reorganized with the aid of the IRaMuTeQ software. After this reorganization, the interferences and the interpretation of the results found by the main researcher were interpreted and inferences were made from them ${ }^{(13)}$.

The IRaMuTeQ can analyze text data in different ways, using the interface between the statistical software $R$ and the lexical analysis of words. It carries out up to five types of analysis: descending hierarchical analysis; similarity analysis; word clouds; classic textual statistics; and specificities and correspondence factor analysis ${ }^{(15)}$.

This study used the word cloud, which organizes and distributes the words graphically according with their frequency in the text, making it possible to identify keywords from a single file, formed from the statements of the participants ${ }^{(15)}$.

It should be mentioned that the use of the software does not exempt the researcher from analyzing and interpreting the results, since it is only a tool to process and systematize information ${ }^{(16)}$. The following words stood out in the word cloud: Patient, Health, Bond, Mental, Person, Professional, and Attention. The convergence between these results and the Public Mental Health Policies led to the creation of three classes, called:"Perceptions about the mental health care carried out in the city"; "The biomedical paradigm in mental health care"; and "Elements for the construction of a new way for professionals to act in mental health".

\section{RESULTS}

The participants of the study were 29 workers from 26 to 68 years old, most of whom were female $(n=24)$. Their time working in the UBS varied from 6 months to 18 years. Only five professionals were specialists in the mental health field, all of whom were psychologists. Three had no post-graduation course (specialization/MS/PhD).

The corpus of the text was created using 591 text segments, 497 of which were analyzed, which corresponded to $84 \%$ of the total. The following words stood out from the word cloud: Pacientes (Patients $-\mathrm{n}=223$ ), Saúde (Health $-\mathrm{n}=141$ ), Vínculo (Bond - $n=134$ ), Mental (Mental - $n=103$ ), Pessoa (Person - $n=89$ ), Profissional (Professional $-\mathrm{n}=71$ ), and Atendimento (Attention $-\mathrm{n}$ $=63$ ), in addition to others that allowed for the content to be combined (Figure 1). From these, tree classes emerged, which are described in detail below.

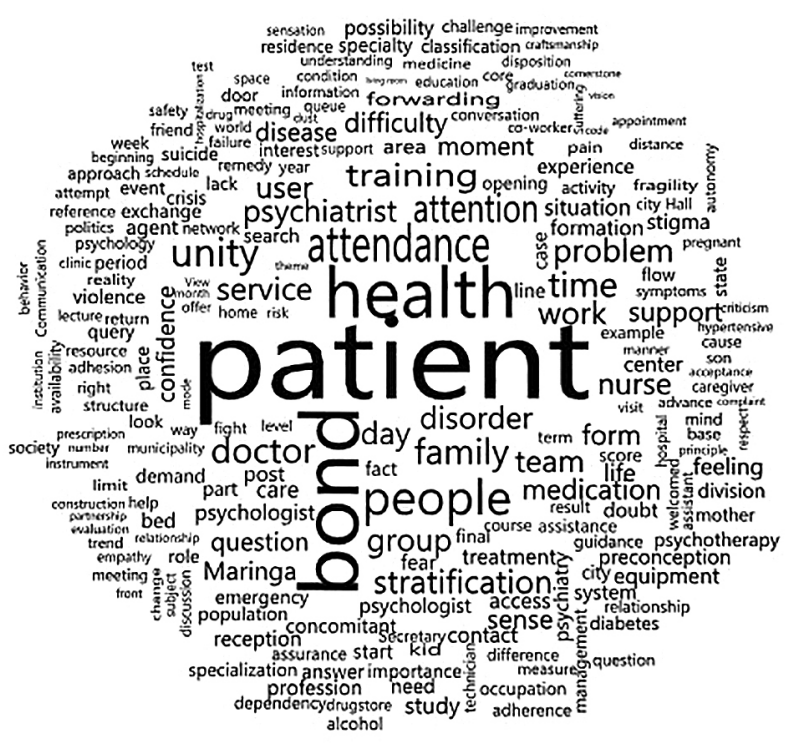

Figure 1 - Word cloud, Words that stood out from the statements, Paraná, Brazil, 2019 


\section{Perceptions about the mental health care provided in the city}

This class shows how participants understand the organization of mental health care in the city. The professionals $(n=28)$ pointed out that the city is privileged in regard to infrastructure, when compared to others.

In this city, assistance is good, when we compare our attention to the nearby cities, where there is no primary care, not only in mental health, it's very bad: there are no general practitioner physicians, no pediatricians, no oncologist, and when there are, they are in small numbers for large cities. (Enf-10)

In this city there is a lot to be done, but we can't complain when we compare with what we see in other cities where there's no CAPS, so here things are going well. (Psic-19)

Although the organization of the services is referred to as a positive, the participants recognize that there are shortcomings in the mental health care, which result from bureaucracy, from the centralization of attention, and from the debility of the process of referrals and counter referrals between the UBS team and the specialized service (the Center for Psychosocial Attention - CAPS).

The mental health care in the city is bad, due to the bureaucracy. The UBS has a bond with the patient; we are the ones who know the patient and the family. We know that the person needs to be send to psychiatric evaluation - we trynot to refer them because we know that the service [CAPS] is not good. To refer them, there must be a mental health stratification; when they get there [CAPS], the professionals take this stratification and throw it away, they make another one. To stratify again with someone who has no bond makes it so the patient doesn't want to say things. So the stratification changes, and they refer them back, claiming we did it wrong. (Med-27)

The structure here is really good, there is only one obstacle: the structure is good, but could be less centralized. All the centers [different types of CAPS] should not be in the same place; they should be decentralized. The centers should be closer to the users, be distributed better through the city, but each city has its reality. (Psic-11).

The health professionals mentioned how should the mental health care attention be for patients in psychic suffering and their families in the scope of the PHC. In addition to the main words, the word cloud also showed the words "family" and "group", which referred to the need to conduct therapy groups for the patients and their families.

What is missing is the offer of larger groups with a psychologist, a social worker, even an occupational therapist, forming the groups in each unit, one for each two teams or for each team, to attend both the families and the patients in a more organized way. (Enf-01)

In primary care, they should make a group with the families of these patients, because exchanging experiences is good. Sometimes, the person who takes care of psychiatric patients feel a little alone, because it's not easy to care [...] We could form a group and discuss the topics, listen to the patients, clarify some doubts. I think this would help a lot since it's something we don't have. (Med-22)

The words"lack" and "qualification" also stood out in the studies. They were associated with the scarcity of professionals that could attend the mental health demands of the subscribed population, in addition to the need to invest on the training of the professionals who work in the $\mathrm{PHC}$, due to the complexity around the therapy for mental disorders. It stands out that, according with the perception of the professionals, although the city provides training and qualification in this area, these are insufficient.

There are not enough professionals, it needs a lot of investment, in addition to the search to the formation of the professionals [...] for us, this is important, that you are encouraged to seek qualification. You come back better prepared, because these realities are very hard, these are families with very hard realities, and we constantly need to work that about us. This encouragement for the management and for the worker to be better prepare must be there. (Psic-20)

There should be more training, because not everyone can deal with them [people under psychic suffering]. (Enf-25)

They could offer more training. Regarding suicide, for instance, there was a nice training, they trained almost all health and assistance workers, but that was it. I feel, for instance, that there should be more events that can discuss the issue of sexual abuse, which happens a lot around here. You can count in the fingers of one hand how many training sessions really were important, that added something new. (Psic-19)

\section{The biomedical paradigm in mental care assistance}

In this class, it was found that the biomedical paradigm persists in health care, since the statements show that the subjects are not understood as a whole. Sometimes, certain professionals may not value the biopsychosocial and spiritual aspects that are part of a human being, focusing only on the disease, and thus, dissociating mental health from other needs the PHC cares for.

When patients were accompanied to the CAPS, I think it was much easier, because there, there are specialized professionals for this type of follow up. Here I have people with mental disorders, diabetes, hypertension, children, pregnant women, so it's difficult to focus on the mental health alone; at CAPS they have all the assistance they need. In this unit, we need a permission for a consultation with psychiatrist; in the CAPS, this attention is already there. (Enf-04)

It was found that professionals are uncomfortable with mental health disorders, and that, since they do not understand them, they are more likely to refer them to others who, traditionally, are known for dealing with this topic, such as psychologists.

Sincemental health requires attention, anything else requires attention, we don't have enough time to spend two hours with a patient like this, noteven one hour. It's complicated! You have to pass itforward, send them somewhere else, also because we are not specialists. (Med-26)

Despite these reports, some workers were sensible to the needs of people under psychic suffering, pointing out how urgent it is to debunk the paradigms and stigmas around mental disorders.

People [the professionals] should be born again! For example, we are six doctors here [UBS] and I am the only one who refer to all other fields; but the other doctors "think" that there is no mental 
health patient in their field. So I asked for the help of a doctor who answers for medium-risk mental health cases in the region; I asked him to come here because the psychologist and I alone were not being able to do it. When he arrived, he asked if there were cases of violence in the area, if they [the other physicians] needed help and they said no! So the head doctor said that they could not help anymore, because my colleagues were unyielding and incomprehensible. (Med-27)

Health workers must be made aware that mental health is not only a responsibility of the psychologist. It depends a lot on the profile of the professional: sometimes the person has a more embracing profile, so they can do it, but many have that feeling of "No! Is it mental health? It's not for me!" There are cases of patients who start crying in the office, and they [other professionals from the team] go call the psychologist or send for the psychologist, because they can't deal with this need. I think this happens because there is a certain prejudice regarding mental disorders. I don't know if it's really an issue of not understanding, maybe the work overload (Psic-07)

\section{Elements for the construction of a new way for profession- als to act in mental health}

Among the words that stood out the most is the term "bond", pointed out as essential for the establishment of a relationship of trust between the subject in the triad service-patient-family. The bond allows for the person to expose their experience in regard to mental disorders, leads to communication and to the adherence to the therapy.

The doctor-patient bond includes a lot: for the patient to adhere to the treatment, he must trust your care, you have to be good technically, to be efficient, to be human, really. You can't be insensitive. You have to be sensitive. (Med-24)

It all comes down to the bond. When the patient has a bond with us [the service], they end up telling us their problems and accepting the treatment better. It's the base for everything: if there is no bond, they don't open up and we don't know what is going on, and we only find out when the problem is advanced. (Enf-18)

From this perspective, the word "trust" was associated to the word bond, and expressed as a base for a holistic and quality assistance, which included the valorization of the experiences of the other and the sensitivity of the professional to attend to the needs of the users.

The patient has to feel they can open up to you. So it's the trust the person feels to open up with you. If they don't trust, they won't tell you something no one knows, they may omit something. (Enf-21)

It is necessary to have trust and acceptance. I say that, starting with trust, even water works! It's knowing that the patient is taking you seriously, that the professional is taking the patient seriously, because usually, since this is not a visible disease, it's difficult for me to feel the depth of the pain of the other, and when you listen, it's already really valuable. (Med-23)

A bond is a matter of trust. I always work with that, so the patient understands we are doing our job, but always searching what is better for them. (Psic-07)
Other elements were mentioned as essential to create a new paradigm of mental health care, such as the demonstration of availability to the patient, embracing, qualified listening, dedication, empathy, and seriousness.

I think that embracing is necessary, to be always open to listen; no patient can arrive at the unit and leave without being heard, that is very bad! Even if I am between one consultation and the other, I receive them immediately. You need it now? We'll listen to you now! Because we leave it for later, what will happen? It's not always possible, but we always try to schedule the fastest possible. (Psic-09)

I think it's important to have empathy with the patient who's suffering, to be able to put ourselves in their shoes and see that they are suffering for this. Empathy is essential, to be serious, to be committed to the work you're doing, to treat the patient with dedication, these are all fundamental elements. (Psic-06)

Most people in the unit need to talk, you need to give them attention, because if the patient likes the care you provide, he'll come back. It's a relationship with you! Our empathy, if I listen to the patient, if I look at him, he feels good about what he's saying and I'm hearing, this is the door to everything. This is what brings the patient to us: you have a conversation and you listen. From the moment you start treating the patient well, they always come back. (Med-29)

\section{DISCUSSION}

From the results above, it can be ascertained that, from the perspective of health workers, mental health care in the PHC has many vulnerabilities, which can compromise the completeness of the care provided to the population. The data from this study reproduce that found in international literature, since there are obstacles to build a new form of mental care ${ }^{(17)}$.

Although the countries published Mental Health Policies, they did not change the structure of the system in accordance with the recommendations from the World Health Organization (WHO). Furthermore, the resources directed to prevent and treat mental disorders are scarce and overload society, especially in developing countries; as a result, more than $80 \%$ of the budget of mental health is invested in psychiatric hospitals ${ }^{(17)}$. Therefore, it is important to develop strategies that change the model of mental health care by decentralizing care and generating collaboration and integration between PHC and specialized services, such as the CAPS. There should be psychiatric beds in general hospitals, since these are closer to the community, as other studies show ${ }^{(17-18)}$.

Discourses have shown that, although there are shortcomings in the attention, the place of study has a good infrastructure, since all UBSs in the city count on the support of psychologists, making it one of the first cities in the country to have these professionals in the Primary Health Care network. In the city under study, the Mental Health Services Network counts on professionals from the CAPS Alcohol and Other Drugs, from the city public psychiatric emergency, from the CAPS II, CAPS III, and CAPS Children and Adolescents, in addition to the Office on the Streets, the Psychiatric Hospitals, and the therapeutic residency ${ }^{(12)}$.

However, many difficulties were faced to install these mental health devices, from ideas that disagreed with the psychiatric reform to the qualification and understanding of the professionals ${ }^{(12)}$, 
who mentioned difficulties in assuming extra-hospital care for people undergoing psychic suffering according to the statements of the participants in this study. The constant challenge is to put the principles of the SUS doctrine in effect, providing Universality, Equality, and Completeness in mental care for the population as a whole, confronting the setbacks to mental health ${ }^{(12)}$.

Health systems are known to be organized according with government structures, and, therefore, for changes to take place in the model for mental health care, it is necessary for political leaders to be engaged ${ }^{(17)}$. This is a challenge, due to the fact that in the last few years Brazilian mental health has been constantly set back. The Ministry of Health published, in 2017, Resolution No. 32, and, in 2019 , the technical note No. $11^{(19-20)}$. Both documents minimize the achievements of the Law of the Psychiatric Reform, since they go back to a hospital-centered asylum model, once bringing psychiatric hospitals and therapeutic residencies into the RAPS.

In 2017, the new National Policy of Primary Care was also put into effect through Decree No. 2.436 (21), limiting the action of the ESF teams and especially of the CHAs, while disregarding National Councils of Health and making the work of PC professionals more precarious. Additionally, in early 2020, the Technical Note No. 03/2020-DESF/SEASP/MS ${ }^{(22)}$ was issued, leading to the dismissal of NASF multiprofessional team and generating difficulties for the creation of spaces for listening, debating, managing cases, and creating bonds with the community. These actions have a negative impact on people in psychic suffering in the units, since it limits access to health services, especially as it is an obstacle for the links that form between services and community, since the $\mathrm{CHAs}$ are the main responsible for the creation and maintenance of this bond; consequently, diagnoses and the beginning of adequate therapies are delayed.

Still, due to the current setbacks in the National Policy of Mental Health (PNSM), Brazil has been going through an unprecedented decline. For 30 years, the mental health care model, based on the basic rights of the citizens with mental disorders/ mental suffering, advanced slowly, but with no interruptions. The budget of the community-based service network is lacking; however, the budget for psychiatric hospitals increased over the last few years. In addition, during the COVID-19 pandemic and during the recess of the National Congress, the Ministry of Health created a workgroup that seeks to revoke many decrees involving the PNSM, putting the functioning of the RAPS at risk ${ }^{(23)}$. Consequently, the encouragement for health professionals to work with good judgment and ability in the care for those with psychic suffering is doubtful.

The reports of the participants have also shown that some general practitioners avoid attending users under psychic distress in the ESFs. Among the reasons given, one that stands out is the idea that those under psychic suffering should only receive care from specialists; there is little time available to listen for these subjects; and this activity is seen as an undesirable extra workload. These reasons are similar to findings in other studies ${ }^{(17,24)}$. These issues are marked by the difficulty in exercising otherness, presumably by prejudice, fear, danger, and for the discomfort caused by mental disorders ${ }^{(3)}$. According with literature and with the statements of the participants of this study, it can be inferred that, although the professionals have some level of preparation to attend those in psychic suffering in the ESF, they prefer not to, possibly due to the reasons already listed.

Regardless, the subject under psychic distress is expected to seek the PHC, since it is supposed to organize the care and articulate between the devices of the Care Network ${ }^{(12)}$. The referrals are implied, in such a way that the person who makes the referral is co-responsible for it and participates in the entire process, including the progress of the case, the provision of care, and the return of the subject to the initial service ${ }^{(25)}$. Professionals must be prepared to provide resolutive and humane assistance, seeking to provide a continuous care ${ }^{(26-27)}$.

However, the discourses show that the system of referrals is insufficient. Cases can only be referred after the risk of the patient has been classified as medium or high; however, there are disagreements in regard to the score attributed in this stratification of risk. Literature points out that, although the evaluation of the complexity of mental disorders is pertinent, general PHC practitioners tend to work based on a traditional and hierarchical model, resorting to the teams of the CAPS without offering complete care ${ }^{(28)}$.

From this perspective, there must be changes in the field of education and in the formation process. Searching for new teaching methods and techniques is necessary to develop ethical, competent, and skillful in the future ${ }^{(29)}$. The use of active methodologies for the formation in health generates now and didactic forms of work, going beyond traditional teaching models. Currently, several innovative tools are employed for teaching in health, such as Realistic Simulations (RS), based on environments and directives of the assistance, which integrally increase the complexity of learning ${ }^{(30)}$. Therefore, mental health care should be incorporated into all disciplines in the syllabus of courses in the health field. This would lead students to be involved since their formation starts, aiming to debunk the idea that mental care is a responsibility of specialized workers.

In the meantime, managers should provide effective and planned qualification sessions that can adequately stratify the risk in mental health care and provide spaces to listen for users and health workers, provoking the exchange of experiences and fomenting care in the territory ${ }^{(3,31)}$. The process of permanent education may raise their awareness for a paradigm change ${ }^{(24)}$, having a positive influence on the quality of care as it allows them to understand psychic distress, to promote dialog in the therapeutic care, and to manage the necessary mental health assistance in the $\mathrm{PHC}^{(2,18)}$. From this perspective, it is important to highlight the importance of the CAPS team for the UBS professionals, to manage cases/therapeutic projects; make all those involve co-responsible; determine a longitudinal and holistic care; and promote bonds between the different professional categories.

However, participants also indicated the elements for the creation of a relationship between professional and user. These elements were in accordance with the principles of the psychosocial paradigm, which include bonds, trust, embracing, qualified listening, dedication, empathy, and seriousness. As a result, the importance of a relationship between professionals and users stands out, in which the "bond" has a special relevance ${ }^{(21)}$.

The embracing and the bond are the support on which the relationship formed in the triad professional-user-family becomes 
strong. This relation goes above technical knowledge and results from understanding and valuing the experiences and feelings of people, in such a way that any demand in the territory must be received, listened to, and answered, even when there is a need to continue attention in secondary services ${ }^{(32-33)}$.

It is also important to develop spaces for participative growing, which can be therapeutic groups that provide embracing, dialog, and self-actualization, since a network is created in which each one can freely express themselves. This motivates personal growth considering adverse situations and the consolidation of bonds in the community, leading to the empowering due to experience exchanges ${ }^{(34-35)}$.

It should be highlighted that, in the statements of the participants, it can be noted that they recognize the importance of developing these practices, but thought themselves exempt from them, attributing this duty to other team members, especially the psychologist. The presence of this professional in the ESFs represents the overcoming of challenges, since it leads to health promotion and to the understanding of the biopsychosocial needs of the community. However, for their actions to be effective, it is important for other health workers to understand their role and that they are co-responsible in the care. Similarly, an integrative review found that the current trajectory of the psychologist in the ESF is marked by work overload, since listening, embracing, and therapeutic interventions are tools used by all professionals in the field of health ${ }^{(36)}$. As a result, the awareness about is needed is there, but there is no interest nor will to carry it out.

Therefore, in order that the assistance is in accordance with the psychosocial paradigm, each professional category must assume the responsibility to attend to each particularity of each subject, family, and community, so they can really advance in the model of mental health care $^{(37)}$.

\section{Study limitations}

The limitation of this study was the fact that other professionals from the field of health were not included, such as nursing technicians and auxiliaries, the dentistry team, and especially community health agents, who were frequently mentioned by the participants as the link that connects the service to the community. The professionals from the secondary health care level, such as those in the CAPS, were also absent. Therefore, for future researches, these professionals should be included, for a broader and more complete perception can be achieved about the mental health services. The perspective of these actors could enrich the understanding about the configuration of mental health care, making it possible to include their real demands and leading to the improvement of health care and to more effective actions. At any rate, the results obtained made it possible to discuss challenges for the PHC mental health, following the principles of the Psychiatric Reform.

\section{Contributions to the field}

The results of this research are expected to subsidize the improvement of a new paradigm of mental health care, by raising the awareness of all health professionals, regardless of their specialty. This would allow them to understand that mental health cannot be dissociated from other needs of the subject and that these must be attended by the PHC, which is responsible for organizing care.

\section{FINAL CONSIDERATIONS}

It could be ascertained that, from the perspective of the professionals, the mental health attention provided in the Primary Health Care has shortcomings that compromise the completeness of care and is in disagreement with the Psychiatric Reform and with the State's Mental Health Guideline. Their statements showed that, despite the good infrastructure in the service, and although they indicate elements to create a new way to act, such as bonds, trust, embracing, listening, dedication, empathy, and seriousness, they do not do this work, leaving the responsibility of doing these activities, mostly, to the psychologist. As a result, there are challenges to consolidate mental health in primary care, such as: the difficulty in providing care to users under psychic distress in the ESF; the limited number of generalist professionals that can attend them; the need for all professional categories to be co-responsible; and the bureaucratic process of referrals and back referrals between the UBS and specialized services.

\section{FUNDING}

This work was carried out with the support of the Coordenação de Aperfeiçoamento de Pessoal de Nível Superior - Brazil (the Coordination for the Improvement of Higher Education Personnel - CAPES) - Funding code 001.

\section{REFERENCES}

1. Secretaria de Estado da Saúde do Paraná. Oficina do APSUS: formação e qualificação do profissional em atenção primária à saúde. [Curitiba, PR]: SESA; 2014[cited 2018 Oct 18]. (Oficina saúde mental; 8). Available from: http://www.saude.pr.gov.br/arquivos/File/APSUS_-_Ed._ Permanente/Oficia_8_-_Saude_Mental/Caderno_08_Saude_Mental.pdf

2. Montemezo H, Silva FD, Muramatsu CK, Amorin IR, Buriola AA, Cazañas EF. Perception of nurses and doctors on the service provided to people with mental disorders in primary care. Cienc Cuid Saude. 2018;17(1):1-7. https://doi.org/10.4025/cienccuidsaude.v17i1.38134

3. Paulon SM, Protazio MM, Tschiedel R. "Eu sei o que é saúde mental!": pesquisar e cuidar como fios da mesma trama. Rev Polis Psique. 2018;8(1):6-32. https://doi.org/10.22456/2238-152X.80412

4. Kenny A, Allenby A. Barriers to nurses providing psychosocial care in the Australian rural context. Nurs Health Sci. 2013;15(2):194-200. https://doi.org/10.1111/nhs.12014 
5. Silva GR, Reis HFT, Dos-Santos EM, Souza MPA, Azevedo RL. Mental health in primary care: perceptions of the family health care team. Cogitare Enferm. 2016;21(2):1-7. https://doi.org/10.5380/ce.v21i2.43861

6. Oliveira EC, Medeiros AT, Trajano FMP, Chaves Neto G, Almeida SA, Almeida LR. Mental health care in the territory: conceptions of primary health care professionals. Esc Anna Nery. 2017;21(3):e20160040. https://doi.org/10.1590/2177-9465-EAN-2017-0040

7. Silva DG, Brito JNPO, Fernandes MA, Almeida CAPL, Lago EC. Conception of family health strategy professionals on mental health in primary care. SMAD Rev Eletr Saude Mental Alcool Drogas. 2017;13(3):118-24. https://doi.org/10.11606/issn.1806-6976.v13i3p118-124

8. Barbosa BVF, Cavalcanti A, Alcântara MCA, Pedroza RM, Ferreira SHV. The role of primary attention in health on the constitution of the network care in mental health. Rev Pesqui Cuid Fundam. 2017;9(3):659-68. https://doi.org/10.9789/2175-5361.2017.v9i3.659-668

9. Côrtes Jr JCS, Souza ERP, Souza MCA, Oliveira RVS, Almeida Jr EHR. Otimização da resolutividade no cuidado em medicina de família e comunidade por meio do apoio matricial: relato de experiência. Rev Saude. 2015;6(2):27-9. https://doi.org/10.21727/rs.v6i2.57

10. Santos ROM, Romano VF, Engstrom EM. Vínculo longitudinal na saúde da família: construção fundamentada no modelo de atenção, práticas interpessoais e organização dos serviços. Physis. 2018;28(2):e280206. https://doi.org/10.1590/S0103-73312018280206

11. Ministério da Saúde (BR). Lei no 10.216, de 06 de abril de 2001. Dispõe sobre a proteção e os direitos das pessoas portadoras de transtornos mentais e redireciona o modelo assistencial em saúde mental. Brasília, DF: MS; 2001 [cited 2018 Oct 1]. Available from: http://www.planalto. gov.br/ccivil_03/leis/leis_2001/l10216.htm

12. Secretaria de Estado da Saúde do Paraná. Linha guia de saúde mental. Curitiba: SESA; 2014[cited 2018 Oct 1]. Available from: http://www. saude.pr.gov.br/arquivos/File/linha_guia_final_de_saude_mental.pdf

13. Bardin L. Análise de conteúdo. São Paulo: Edições 70; 2011.

14. Minayo MCS. O desafio do conhecimento: pesquisa qualitativa em saúde. São Paulo: Hucitec; 2014.

15. Souza MAR, Wall ML, Thuler ACMC, Lowen IMV, Peres AM. The use of IRAMUTEQ software for data analysis in qualitative research. Rev EsC Enferm USP. 2018;52:e03353. https://doi.org/10.1590/S1980-220X2017015003353

16. Lahlou S. Text mining methods: an answer to Chartier and Meunier. Pap Soc Represent [Internet]. 2012[cited 2018 Oct 1];20(2):38.1-7. Available from: http://www.psych.lse.ac.uk/psr/PSR2011/20_39.pdf

17. Shen GC, Eaton J, Snowden LR. Mainstreaming mental health care in 42 countries. Health Syst Reform. 2017;3(4):313-24. https://doi.org/10.1 080/23288604.2017.1356424

18. Hogan M. Mental health reform under policy mainstreaming: needed, but uncertain. Epidemiol Psychiatr Sci. 2014;23(1):11-6. https://doi. org/10.1017/S2045796013000632

19. Ministério da Saúde (BR). Resolução n 32, 14 de dezembro de 2017. Estabelece as Diretrizes para o Fortalecimento da Rede de Atenção Psicossocial (RAPS). Brasília, DF: MS; 2017[cited 2018 Oct 1]. Available from: https://bvsms.saude.gov.br/bvs/saudelegis/cit/2017/res0032_22_12_2017.html

20. Ministério da Saúde (BR). Nota Técnica no 11, de 2019. Esclarecimentos sobre as mudanças na Política Nacional de Saúde Mental e nas Diretrizes da Política Nacional sobre Drogas. Brasília, DF: MS; 2019.

21. Ministério da Saúde (BR). Portaria n².436, de 21 de setembro de 2017. Aprova a Política Nacional de Atenção Básica, estabelecendo a revisão de diretrizes para a organização da Atenção Básica, no âmbito do Sistema Único de Saúde (SUS). Brasília, DF: MS; 2017 [cited 2018 Oct 1]. Available from: https://bvsms.saude.gov.br/bvs/saudelegis/gm/2017/prt2436_22_09_2017.html

22. Ministério da Saúde (BR). Nota Técnica no 3, de 28 de janeiro de 2020. Núcleo Ampliado de Saúde da Família e Atenção Básica (NASF-AB) e Programa Previne Brasil. Brasília, DF: MS; 2020.

23. Conselho Federal de Enfermagem (BR). Cofen alerta sobre risco de retrocesso na política de saúde mental [Internet]. Brasília, DF: Cofen; 2020[cited2021 Jan 14]. Available from: http://www.cofen.gov.br/cofen-alerta-sobre-risco-de-retrocesso-na-politica-de-saudemental_83702.html

24. Hirdes A, Scarparo HBK. The maze and the minotaur: mental health in primary health care. Cienc Saude Colet. 2015;20(2):383-93. https://doi org/10.1590/1413-81232015202.12642013

25. Kantorski LP, Coimbra VCC, Oliveira NA, Nunes CK, Pavani FM, Sperb LCSO. Psychosocial attention of children and adolescents: interfaces with the health network by the referral and counter-referral system. Texto Contexto Enferm. 2017;26(3):e1890014. https://doi. org/10.1590/0104-07072017001890014

26. Pessoa Jr JM, Nóbrega VKM, Oliveira JDS, Miranda FAN. Historical trajectory of an alternative service in mental health in the light of oral history. Cienc Cuid Saude. 2013;12(2):298-306. https://doi.org/10.4025/cienccuidsaude.v12i2.18728

27. Pessoa Jr JM, Miranda FAN, Dutra SVO, Santos EC, Silva MB. Psychiatric reform and mental disorders in the family health strategy: family and professional opinion. Cienc Cuid Saude. 2014;13(2):271-7. https://doi.org/10.4025/cienccuidsaude.v13i2.19402

28. Teixeira MR, Couto MCV, Delgado PGG. Primary care and collaborative care in children and adolescents psychosocial interventions: facilitators and barriers. Cienc Saude Colet. 2017;22(6):1933-42. https://doi.org/10.1590/1413-81232017226.06892016

29. Salvador CAB, Toniosso JP, Nogueira LDP, Larêdo SMP. Simulação realística, estratégia metodológica para a formação de profissionais na área da saúde: uma revisão integrativa. Rev Bras Educ Saude. 2019;9(4):58-64. https://doi.org/10.18378/rebes.v9i4.6466

30. Negri EC, Mazzo A, Martins JCA, Pereira Jr GA, Almeida RGS, Pedersoli CE. Clinical simulation with dramatization: gains perceived by students and health professionals. Rev Latino-Am. Enfermagem. 2017;25:e2916. https://doi.org/10.1590/1518-8345.1807.2916 
31. Penido CMF, Castro BP, Coimbra JR, Baker VDSIS, Franco RF. Mental health in primary health care: should matrix support be added or split? Rev Polis Psique. 2018;8(1):33-51. https://doi.org/10.22456/2238-152X.80415

32. Drescher A, Both JE, Hildebrandt LM, Leite MT, Piovesan SMS. Concepts and interventions on mental health in the perspective of family health strategy professionals. J Nurs UFPE. 2016;10(supp 4):3548-59. https://doi.org/10.5205/reuol.9681-89824-1-ED.1004sup201606

33. Frosi RV, Tesser CD. Mental health care practices in primary health care: an analysis based on experiences developed in Florianópolis, Brazil. Cienc Saude Colet. 2015;20(10):3151-61. https://doi.org/10.1590/1413-812320152010.10292014

34. Rangel CT, Miranda FAN, Oliveira KKD. Communitarian therapy and nursing: the phenomenon and its contexto. Rev Pesqui Cuid Fundam. 2016;8(1):3770-9. https://doi.org/10.9789/2175-5361.2016.v8i1.3770-3779

35. Lemes AG, Nascimento VF, Rocha EM, Moura AAM, Luis MAV, Macedo JQ. Integrative community therapy as a strategy for coping with drug among inmates in therapeutic communities: documentary research. SMAD Rev Eletr Saude Mental Alcool Drogas. 2017;13(2):101-8. https:// doi.org/10.11606/issn.1806-6976.v13i2p101-108

36. Rocha MB, Almeida MMS, Ferreira BO. Possibilities of professional performance of the psychologist in the Primary Health Care context. Rev Bras Promoc Saude. 2016;29(1):117-23. https://doi.org/10.5020/18061230.2016.p117

37. Rodrigues TFCS, Sanches RCN, Oliveira MLF, Pinho LB, Radovanovic CAT. Feelings of families regarding drug dependence: in the light of comprehensive sociology. Rev Bras Enferm. 2018;71(suppl 5):2272-2279https://doi.org/10.1590/0034-7167-2018-0150 